\title{
SMART LOGISTICS IN THE EVOLUTION OF THE LOGISTICS
}

\section{IZABELA DEMBIŃSKA}

University of Szczecin, Faculty of Management and Economics of Services, POLAND

e-mail: izabela.dembinska@wzieu.pl

\begin{tabular}{l|l}
$\begin{array}{l}\text { RECEIVED } \\
\text { ACCEPTED }\end{array}$ & $\begin{array}{l}18 \text { January } 2018 \\
\text { 2 September } 2018\end{array}$ \\
CLASSIFICATION & R49 \\
KEYWORDS & $\begin{array}{l}\text { smart logistics, logistics, supply chain } \\
\text { The aim of the article is to try to define the scope of the meaning of the concept of smart logistics as well } \\
\text { as to determine the place in the evolution of the logistics. The definitions available in the literature were } \\
\text { analyzed and the author's definition was proposed. The attributes of the smart logistics concept are indicated. } \\
\text { The stages of logistics concept evolution were tracked and shown how of smart logistics concept determines } \\
\text { the contemporary management of supply chains. The Internet of Things was discussed as a determinant of the } \\
\text { development of intelligent logistics. }\end{array}$
\end{tabular}

\section{Introduction}

The development of digitization and the Internet creates new conditions for the economic and social spheres. For business, they are an inspiration to change and reconfigure business models. Modern IT technologies irreversibly transform traditional business, and the network is slowly becoming a common space for both stationary and typically virtual businesses. 
Intelligent technical and technological solutions have become a great challenge for modern logistics. Creating a multitude of ideas for different areas of logistics, they contribute to greater efficiency and effectiveness of processes.

Cybersecurity is becoming a prerequisite for intelligent supply chains. It determines not only the effectiveness and efficiency of functioning, but also creates conditions for the implementation of logistics processes in cyberspace.

The aim of the study is to determine the scope of the meaning of the smart logistics concept and to show the place of this concept in the evolution of the logistics. The article is a conceptual and review nature.

\section{SMART Logistics - definition and related concepts}

The concept of "smart" appears more and more often in various areas of social and economic life. Most often it refers to things like a smartphone, smart car, smartwatch, smart house, or to business areas, such as smart specialization, smart logistics or socio-economic spaces, such as smart city. It is often used in different contexts, as it is vague in itself because it can have different meanings for different people.

The reference of the concept of smart to logistics requires a broader discussion, as there is still a lack of definition of the smart logistics concept in the literature on the subject, what is more - there is no broader discussion on this subject. When trying to determine the semantic field of the smart logistics concept, the understanding of the word "smart" should first be clarified. This is important, because the direct translation of the word from English is not applicable in this case. Colloquially, it is translated into Polish in the sense of "wise" or "clever". The term "smart", currently used in various areas of social and economic life, is interpreted in the sense of the word "intelligent" (Dembińska, Frankowska, Malinowska, Tundys, 2018, pp. 9-10). The premise of such a statement is often the use of these concepts interchangeably. Assuming this assumption, another semantic problem arises, that is, what interpretation to use for the word "intelligent". The Dictionary of the Polish Language (Słownik Języka Polskiego) requires that the word be used in the sense of a thoughtful, non-stupid, intelligent, wise, smart, knowledgeable, capable, and therefore quite similar to the word "smart". The analysis of literature gives the basis to claim that there is another understanding of the word "intelligent", which is based on intelligent computer technology (ICT). Interesting is the position regarding this issue by M. Weiser (1996). He notes that the term "intelligent" expresses current technological changes and thus shows its dependence on time. As he argues, the "smart home" of 1935 had electric light in every room, the "smart house" of 1955 had a TV set and a telephone in every room, and the "smart home" of 2005 had a computer in every room. With which you can agree that the word "intelligent" should be understood in this context in the context of implementing innovation and the availability of state-of-theart technology, Sah believes that everything that limits human efforts and automates tasks should be described as "intelligent" (Sah, 2016, pp. 55-57).

It can be assumed that in this way the term "smart logistics" should be understood. It should be emphasized that the acceptance of such delimitation of the semantic field for this concept is an open matter, requiring further discussion.

The explanation of the concept of intelligent logistics can also be based on the meaning of the terms "smart products" or "smart services". Intelligent products and services are those that have taken over from people the part of their abilities, freeing them from doing work. Intelligent products and services evolve from the level of new technologies to the level of even newer technologies (Fleisch, Christ, Dierkes, 2005, pp. 3-37), which shows the dependence on the time mentioned by M. Weiser. Therefore, two conclusions can be drawn. First, 
a technology-based approach to defining 'smart products' and 'smart services' is therefore used to define 'intelligent logistics'. Secondly, due to the fact that "intelligent logistics" changes depending on the current technology, it is characterized by time dependence and it is necessary to determine the current level of technology to interpret the concept of intelligent logistics (Uckelmann, 2008, pp. 273-284; Windt, Hülsmann, 2007, pp. 4-16). In other words, the temporal connotation of the concept of intelligent logistics affects its semantic field, determined by the level of technology at a given time.

As used herein, the term "Logistics 4.0 " is also used. This concept is derived from the concept of "Industry 4.0" or "Industry 4.0". It is worth noting that the name "Industry 4.0" is used in Europe, in the United States and AngloSaxon countries the name "Internet Things" or "Internet Everythings" is used. The term "Industrie 4.0" appeared for the first time in the draft High Tech Strategy of the German government, promoting the computerization of manufacturing processes, and was for the first time officially used at the Hannover trade fair in 2011 (Czym jest przemysł 4.0, część 2, 2017). Industry 4.0 is a collective term meaning the integration of intelligent machines, systems and introducing changes in production processes, which aim to increase production efficiency and introduce the possibility of flexible product changes. Industry 4.0 applies not only to technology, but also to new ways of working and, therefore, also to the new role of people in the industry (Czym jest przemysł 4.0, część 1, 2017).

Industry 4.0 is the next, fourth stage in the evolution of the industry. As earlier stages, the following are listed:

1. Industry 1.0 - mechanization, which was characterized by the invention and implementation of a steam engine.

2. Industry 2.0 - electrification, which contributed to the displacement of steam engines and the development of production lines, adapted to production in large series.

3. Industry 3.0 - digitization, the domain of which were computers and data processing systems, enabling machine control via software.

The essence of industry 4.0 boils down to the ubiquitous combination of machines, products, systems and people, which will enable them to communicate, thanks to which they form a mutual management network (Wegener, $2015,343-358$ ). What differentiates phase 4.0 from phase 3.0 in the development of industry is the combination of mobile technologies with stationary automation (Paprocki, 2016, pp. 22-23).

The term e-logistics is also used among the concepts related to intelligent logistics (Dembińska-Cyran, 2005b, pp. 177-193). In contrast to the definitions of "smart logistics" or "intelligent logistics", many explanations for the term e-logistics can be found in the literature. According to the definition of W. Wieczerzycki (2012, p. 49), e-logistics is based on the use of the latest information technologies to support logistic management of the enterprise and to support the management of its business environment, especially supply chains. E-logistics uses the Internet and various types of IT systems in logistics processes and is part of the concept of electronic supply chain management (Palonka, 2008, pp. 325-336; Valkova, 2013, pp. 119-128). E-logistics does not involve the physical transport of raw materials and products, because it concerns the "virtual" supply chain planning and coordination of all logistic processes aimed at the maximum automation and streamlining of processes through the use of computer networks (Wieczerzycki, 2012, p. 49).

The next stage of the industry's evolution is mentioned - about "Industry 5.0", that is about industry 5.0. The term "Industry 5.0" was introduced in 2015 by Michael Rada as a response to the threat of limiting the role of man in Industry 4.0. Just as industry 4.0 is characterized by cyberphysical systems, the attribute of industry 5.0 is the interaction between man and machine/robot (Figure 1). 


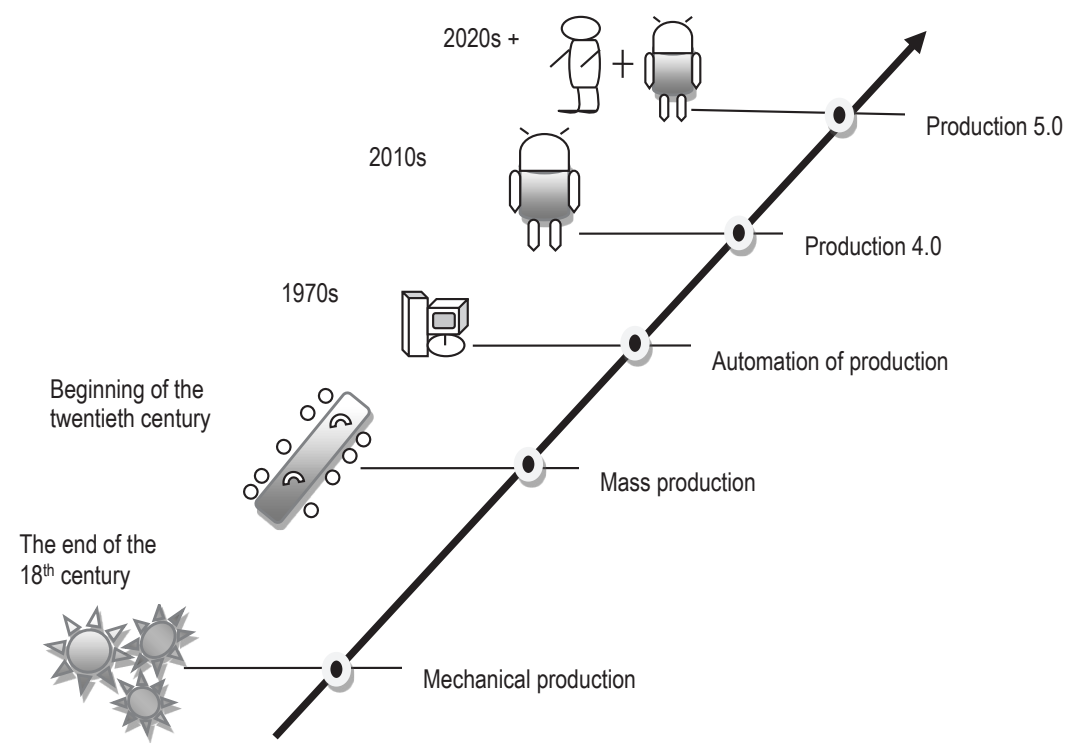

Figure 1. Stages of industry evolution

Source: own study.

In accordance with the Council's assumptions, in the concept of industry 5.0, man and machine are to form a functional whole. This particularly applies to robots that are to cooperate with people as devices cooperating in a direct and interactive way. In factories in robots and work zones, people are supposed to overlap and integrate, in contrast to current, separated work models (Trendy..., 2018).

S. Gotfredsen (2016) argues that Industry 5.0 reflects the growing need for individualisation of production, an implication of the increasingly individualized demand reported by customers. He believes that in the cooperation of man and machine, man introduces the element of creativity indispensable in the model of personified production. Therefore, it can be expected that in the near future a logistics model 5.0 will also be created.

\section{The Internet of Things as a determinant of the development of intelligent Logistics}

The Internet of Things is considered the next stage of the information revolution. It significantly affects the social and economic spheres by modifying business models. The concept of the Internet of Things was first used by the British entrepreneur and founder of Kevin Ashton's start-ups in 1999. This idea was formulated to describe a system in which the material world communicates with computers (exchanges data) using ubiquitous sensors. The essence of the Internet of Things does not lie in the devices themselves, but in the latent potential of data collected and sent by them.

There are many definitions of the term "Internet of Things". According to the Cisco Internet Business Solutions Group (Cisco IBSG), the internet of things can be said from the moment when the number of objects and objects connected to the Internet has exceeded the population. In 2000, there were 6 billion people in the world, and only 500 million devices were connected to the network. At the turn of 2008 and 2009 . The number of devices connected to the Internet for the first time exceeded the number of inhabitants of the country. It can be said that it was at that 
time that the Internet of Things was born. In 2010, a huge increase in the number of smartphones and tablets caused that the number of devices connected to the network amounted to 12.5 billion. On average, it was 1.84 of such a device per capita of the globe (population reached 6.8 billion). In 2011, the population reached 7 billion, while the number of devices connected to the network amounted to 13 billion (other sources provide 12.5 billion devices, including virtually every computer and significantly more than 1 billion smartphones) (Kwiatkowska, 2014, pp. 61-62). According to the "We Are Social" report (Digital in 2017, 2018) on the Internet, social media and the mobile industry, the number of Internet users in the world in January 2017 was 3.773 billion people (Table 1).

Table 1. Number and percentage of Internet users, social media and mobile devices in the world in January 2017

\begin{tabular}{ccccc}
\hline Total population & Internet users & Active social media users & Unique mobile users & Active mobile social users \\
\hline 7.476 bln & $3.773 \mathrm{bln}$ & $2.789 \mathrm{bln}$ & $4.917 \mathrm{bln}$ & $2.549 \mathrm{bln}$ \\
\hline urbanization: & penetration: & penetration: & penetration: & penetration: \\
$54 \%$ & $50 \%$ & $37 \%$ & $66 \%$ & $34 \%$ \\
\hline
\end{tabular}

Source: Digital in 2017 (2018).

It is estimated that by 2020, these devices will have over 50 billion, while the population is expected to increase to 7.6 billion. On average over six (exactly 6.58) devices connected to the network will fall on every inhabitant of the world. These estimates do not take into account the rapid progress of Internet technology and the devices that connect to it. What is more, this indicator would be much higher if only the participants of the digital society should be considered, and not the inhabitants of the whole globe, many of whom do not have access to the network (Kwiatkowska, 2014, pp. 61-62).

The Internet of the system of things consists not only of objects, but also processes, data, people, and even animals or atmospheric phenomena - everything that can be treated as a variable (Kolenda, 2018, p. 8).

- objects that can communicate, receive commands or transmit information,

- ICT network mediating in dialogue,

- IT systems and solutions for processing the collected data and transferring information to the devices (Kolenda, 2018, p. 4).

The consequences of the dissemination of the idea of the Internet of Things are not yet definitively determined, although one can be sure that the potential for dialogue between users and machines is enormous. The direction of development consists in increasing the interaction between a human being and an object. This in turn raises the need to analyze ever larger amounts of data, identify information contained in them, which is important for a given action and making optimal decisions about future behaviors. The source of this "intelligence" is analytics and the ability to use it even in the most complex decision environments. Direct business benefits, and thus financial benefits resulting from the wide application of the Internet of Things, can be found at the three levels of maturity proposed by Kirk Borne:

a) "Data to Discovery", where, based on new data and with the use of analytics, phenomena of which existence has not been known until now can be found and identified - for example, new disease patterns found thanks to detailed data from telemedicine devices; 
b) "Data to Decisions", where the action can be taken on the basis of the acquired knowledge, often even autonomously - an example may be the sending of a welcome message and product recommendations to the returning customer, but also an emergency shutdown of the power turbine at the time of failure;

c) "Data to DollarsDividents", where the combination of two previous skills emerges real financial benefit for the organization or a new opportunity for business development (Kolenda, 2018, p. 4).

The Internet has radically changed our way of life. He transferred mutual relations between people to the virtual level in various areas, ranging from professional life to private life, especially socializing. The Internet of Things has the potential to add a new dimension to this process, enabling communication not only of people with smart objects, but also communication between such intelligent objects. This leads to ensuring communication always and everywhere, i.e. anywhere, using every medium of information and anything, that is everything, not just people, preferably using any network and all services. It is widely believed that the Internet of Things will lead to a much larger revolution than the Internet and mobile telephony put together. Currently, at least half of Internet connections, at least one of the parties is the thing (Kwiatkowska, 2014, p. 60).

The Internet of Things creates four types of offered functionalities:

- autonomy,

- optimization.

- control,

- monitoring.

The possibilities associated with these functionalities cause the emergence of new business models. Ten basic types can be identified (Wielki, 2016, pp. 211-212):

1. Business models based on the philosophy of "everything as a service".

2. Business models based on the use of new forms of outsourcing.

3. Business models based solely on data and their use.

4. Business models based on offering additional services to clients related to the physical product.

5. Business models based on the offering of intelligent products will be the source of additional benefits for the client.

6. Business models based on behavioral profiling.

7. Hybrid business models.

8. Business models based on offering loT platforms.

9. Business models based on offering comprehensive loT infrastructure solutions.

10. Business models based on offering enhanced services.

As for the first group, the most important "trend" within it is the product-as-a-service model. Its development is related to the more and more widely observed migration processes, from the scheme consisting in the purchase of a product by the customer in favor of one in which the producer retains ownership of it, while the customer uses it, paying for its real use. The development of functionalities related to intelligent, connected products offers great opportunities in this respect. The development of intelligent systems also allows the implementation of business models based on offering new forms of outsourcing. As for the third category, the development of intelligent connected devices enables the collection of huge amounts of various types of data that can be used to create business models based on their use. The development of the Internet of Things also gives the opportunity to implement business models based on offering customers additional services related to the physical product purchased and used by 
them. Another group is business models based on offering intelligent products to customers, which are a source of additional benefits for them. Another group of business models are those based on the use of behavioral profiling. A certain compromise between the product-as-a-service category and the traditional acquisition of products by customers are hybrid business models. In this case, their sale may be combined, for example, with different types of service contracts based on remote monitoring of the device's functioning. Another group is business models based on offering loT platforms to users. The next group of business models are those based on offering comprehensive IOT infrastructure solutions. The last group is business models based on offering extended services. This forwardlooking category includes solutions based on the use of data and information collected by entities providing various IoT services and offering on their basis their own (Wielki, 2016, pp. 213-214).

\section{A place of intelligent logistics in the evolution of logistics}

In the literature on the subject you can find many shots showing the evolution of logistics (Bowersox, 1978; Gołembska, 1994; Skowronek, Sarjusz-Wolski, 1995; Blaik, 2002). The authors agree in principle that the development of logistics in the twentieth century was divided into the following stages (Kadłubek, 2010, p. 55):

- awakening stage of the logistics - mid-50s in the US,

- the stage of defining and conceptualizing the theory of logistics and its first applications in practice - the 1960 s in the US and the early 1970s in Western Europe,

- the stage of creating dimensions of integrated logistics - the second half of the 70 s and the mid-1980s,

- the stage of dynamic development of logistics as an integrated concept of business management - the second half of the 80 s and the first half of the 90 s,

- the stage of development of the supply chain concept - the second half of the $90 \mathrm{~s}$.

Entering the 21st century, the leading determinants shaping the functioning of logistics were, among others deepening specialization in the supply chain (Dembińska-Cyran, 1996; Dembińska-Cyran, 2004), sustainable development (Dembińska-Cyran, 2005a), customer relationship management (Dembińska-Cyran, Hołub-Iwan, Perenc, 2004). Scenarios or directions of logistics development in the 21 st century have become the subject of many studies. Significant conclusions include the study "Global Logistics 2015+", made by DB Schenker and the Technical University of Berlin. Noteworthy is the report "2016 The Future Value Chain", prepared by Capgemini based on research conducted since 2005, supplemented with the report Succeeding In a Volatile Market. 2018 The Future Value Chain (Bujak, Gębczyńska, Miller, 2014, pp. 868-880). The above-mentioned studies show that key factors affecting future supply chains are changes in consumer purchasing behavior and greater use of modern technologies in information and physical flows. Particular attention is paid to three interrelated challenges:

1. The basic element is the development of new ways of cooperation, including sustainable changes in the field of culture, economic cooperation and planning of new activities, the use of economic effects.

2. By building an appropriate culture of cooperation between companies, creating the basis for easier and more effective exchange of information: the report emphasizes that "it is best to manage increasingly complex supply chains thanks to transparency".

3. Only an open collaborative environment can generate the right changes and flexibility of future value chains and effectively address the impact on physical flow of goods, energy price changes, changes in population density and other external forces (Bujak, Gębczyńska, Miller, 2014, pp. 868-880). 
The main factors for the development of logistics in the 21 st century are undoubtedly the dynamically developing information technologies and the spread of the Internet and the creation of new and broad possibilities. These determinants have created a wide field for the development of intelligent logistics, based on the use of advanced information and communication technologies in logistics, which gives the opportunity to define it as "intelligent".

In the DHL "Logistics Trend Radar" report for 2016, twenty-six key trends and challenges for modern logistics were selected. Most of them are associated with the development of artificial intelligence and personalization. It is planned to develop intelligent supply chains using systems of self-learning or self-learning using a computer, and to promote the Batch Size One and On-demand Delivery options. Created to exert a significant influence on logistics, the on-demand delivery option will enable consumers to deliver their purchases in the place and time chosen by them thanks to the use of flexible courier services. The Batch Size One option explores what could happen if consumer demand for highly personalized products has met mass production over the coming and rapidly changing supply chains that require logistics service providers to act quickly and to respond flexibly to changes in time and the place of manufacture (Logistics Trend Radar 2016).

Intelligent logistics creates many new solutions. At the same time, it creates opportunities for existing, wellknown solutions to undergo development, becoming more perfect, more effective. Table 2 presents examples of solutions that implies the development of intelligent logistics.

\section{Table 2. Selected solutions in the field of intelligent logistics}

\begin{tabular}{ll}
\hline \multicolumn{1}{c}{ Dimension } & \multicolumn{1}{c}{ Key solutions } \\
\hline Transport & $\begin{array}{l}\text { Security systems, route planning systems, unmanned trucks, intelligent transport management systems, intelligent highway, } \\
\text { navigation systems, augmented reality }\end{array}$ \\
\hline Warehouse & $\begin{array}{l}\text { RFID, intelligent warehouse, intelligent distribution center, intelligent forklift, intelligent racking, automation of picking, } \\
\text { augmented reality }\end{array}$ \\
\hline Production & Production control systems, quality control systems, intelligent assembly systems \\
\hline Supply chain & e-supply chain, e-commerce, virtual supply network \\
\hline
\end{tabular}

Source: own study.

With regard to the term used in logistics 4.0 , the development of logistics can be divided into the following stages (Figure 2):

- Logistics 1.0 - until the end of the 18th century,

- Logistics 2.0 - until the end of the 1960s,

- Logistics 3.0 - until the end of the 20th century,

- Logistics 4.0 from the beginning of the XXI century.

The logistics entry into the logistics phase 4.0 also triggered changes in the perception of the supply chain, which caused that the basic attributes of the supply chains are not only flexibility and agility, but also digitalization, which becomes their determinant (Figure 3). The emergence of a "digital client" ("connected customer") causes more pressure on suppliers, demanding a better adaptation of products to customers' demands and preferences, quick and trouble-free delivery. Digitization in the supply chain undoubtedly inspires, but also forces the creativity in the operational and tactical areas, making customer relations on the one hand more real, on the other hand more 
effective. Therefore, it can be concluded that the creation of competitive advantage by intelligent supply chains takes place on three levels:

- data analysis supporting advanced decision making,

- interaction between people and machines increasing the functionality and efficiency of logistics processes,

- innovation.

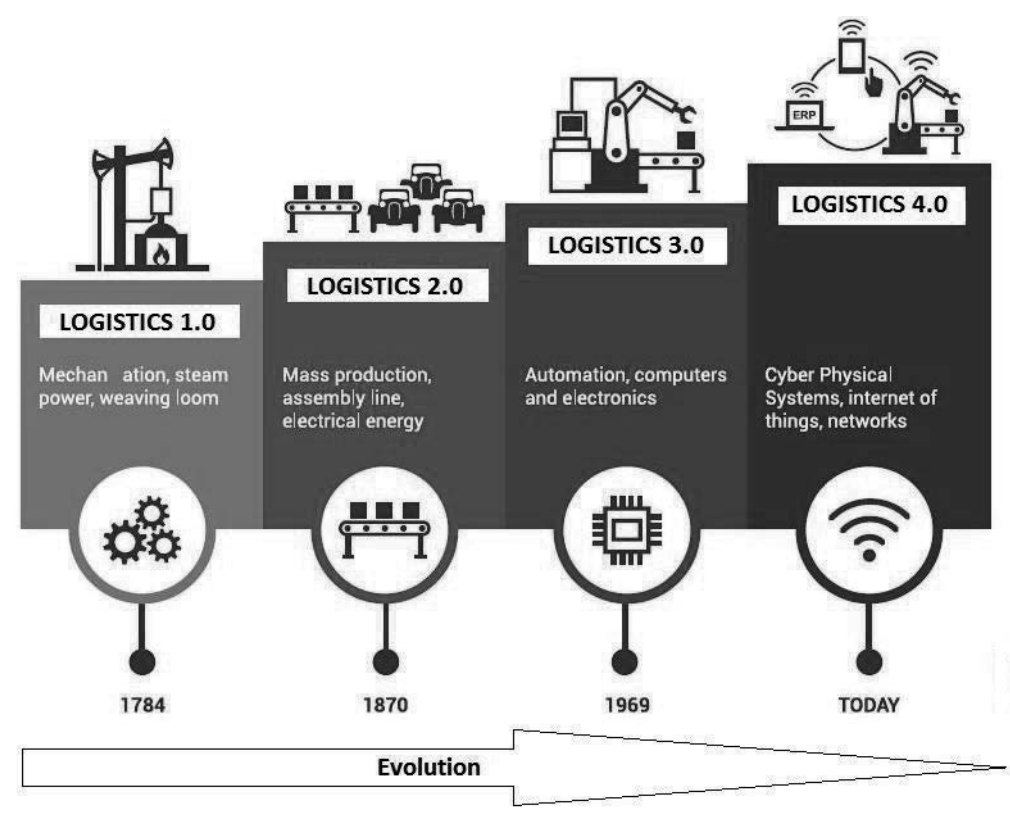

Figure 2. Stages of logistics evolution

Source: own study based on: Industry 4.0... (2017).

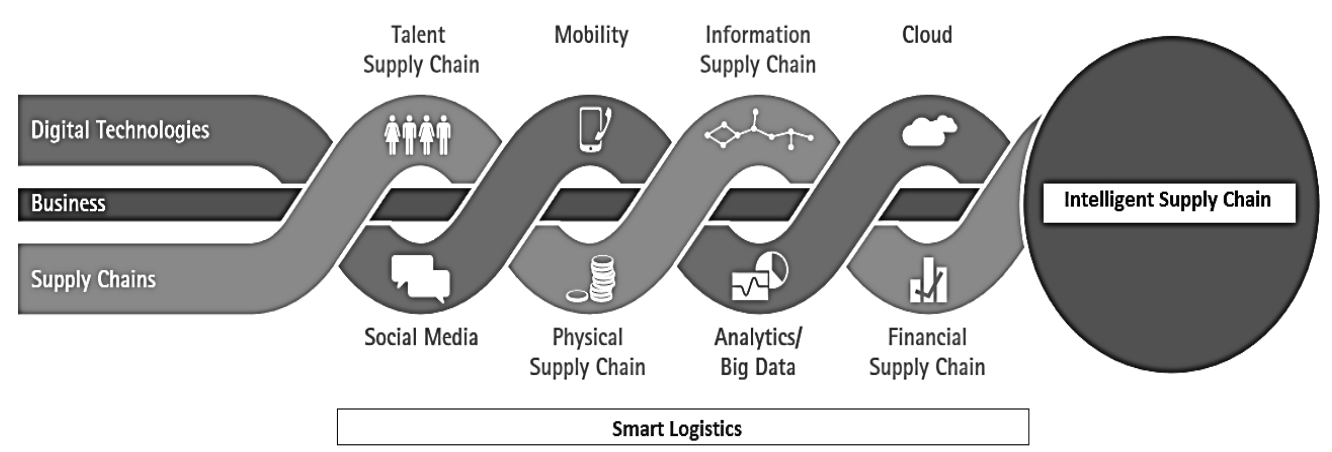

Figure 3. The concept of Intelligent Supply Chain

Source: own study based on: Supply chain... (2018). 
It can be assumed that the supply chain is intelligent when it allows predicting customer demands, sensing changes in supply and demand and responds quickly to unplanned events. It uses information and quick decisionmaking methods in managing such a supply chain as a substitute for additional resources (What is Intelligent Supply Chain). However, it should be considered whether these are the only attributes of an intelligent supply chain. Do not look at the problem wider. Therefore, it can be assumed that the so-called "Supply chain intelligence" can be expected in many of its functional and organizational areas, such as transport, storage, supply, production, which has already been noticed before.

\section{Conclusions}

Analyzing the impact of intelligent technical and technological solutions on the logistics and supply chain, it is worth considering the effects of their application. In general, you can specify the following areas and effects:

- supply chain structure - one can expect a "slimming" of the supply chain, reconfiguration of cells,

- management of logistics processes - more efficiency and effectiveness can be expected,

- relations in the supply chain - you can expect a closer relationship, better conditions for cooperation in the operating and tactical field.

Of course, the basic condition for obtaining these effects is the ability to properly use intelligent solutions, and this in turn depends on the competence of the logistics staff. In other words, it should be expected that the competences of the logistics staff will be directed to intelligent solutions to serve the development of intelligent logistics and intelligent supply chains.

\section{References}

Blaik, P. (2002). Logistyka. Warszawa: PWE.

Bowersox, D.J. (1978). Logistical Management. New York: McMillan Publishing Co.

Bujak, A., Gębczyńska, A., Miller, R. (2014). Współczesna logistyka - obszary i kierunki przekształceń. Logistyka, 1, 868-880.

Czym jest Przemysł 4.0? część 1 (2017). Retrieved from: http://przemysl-40.pl/index.php/2017/03/22/czym-jest-przemysl-4-0.

Czym jest Przemysł 4.0? część 2 (2017). Retrieved from: http://przemysl-40.pl/index.php/2017/05/03/czym-jest-przemysl-4-0-czesc-2.

Dembińska-Cyran, I. (1996). Outsourcing jako narzędzie Lean Management. Ekonomika i Organizacja Przedsiębiorstwa, 4, 7-9.

Dembińska-Cyran, I. (2004). 4 PL-nowa generacja operatora logistycznego. Logistyka, 4, 45-49.

Dembińska-Cyran, I. (2005a). Zastosowanie tramwajów towarowych w obsłudze dostaw na obszarze miasta. LogForum, 1 (3), 1-14.

Dembińska-Cyran, I. (2005b). Internet we współczesnej logistyce. Europa Regionum, 8, 177-193.

Dembińska-Cyran, I., Hołub-Iwan, J., Perenc, J. (2004). Zarządzanie relacjami z klientem. Warszawa: Difin.

Dembińska, I., Frankowska, M., Malinowska, M., Tundys, B. (2018). Smart Logistics. Kraków-Legionowo: Wydawnictwo edu-Libri.

Digital in 2017: Global Overview (2018). Retrieved from: https://wearesocial.com/special-reports/digital-in-2017-global-overview.

Fleisch, E., Christ, O., Dierkes, M. (2005). Die betriebswirtschaftliche Vision des Internets der Dinge. In: E. Fleisch, F. Mattern (eds.), Das Internet der Dinge. Springer.

Gołembska, E. (1994). Logistyka jako zarządzanie łańcuchem dostaw. Poznań: Wydawnictwo Akademii Ekonomicznej w Poznaniu.

Gotfredsen, S. (2016). Bringing back the human touch: Industry 5.0 concept creating factories of the future. Manufacturers' Monthly, June 15. Retrieved from: www.manmonthly.com.au/features/bringing-back-the-human-touch-industry-5-0-concept-creatingfactories-of-the-future/.

Trendy zmian (2018). Retrieved from: www.kolozyciaproduktu.pl/zmiana/trendy-czwartej-rewolucji-przemyslowej/przemysl-5-0. Industry 4.0. Are we there yet? (2017). Retrieved from: http://wbj.pl/industry-4-0-are-we-there-yet. 
Kolenda, P. (ed.). (2018). Internet Rzeczy w Polsce. Raport. IAB Polska. Retrieved from: https://iab.org.pl/wp-content/uploads/2015/09/ Raport-Internet-Rzeczy-w-Polsce.pdf.

Kadłubek, M. (2010). Fazy i kierunki rozwoju logistyki zorientowanej na klienta. Logistyka, 4, 55-60.

Kwiatkowska, E.M. (2014). Rozwój Internetu rzeczy - szanse i zagrożenia. Kwartalnik Antymonopolowy i Regulacyjny, 8 (3). Retrieved from: https://ikar.wz.uw.edu.pl/numery/22/pdf/60.pdf.

Logistics Trend Radar (2016). DHL Trend Research. Retrieved from: http://www.dhl.com/content/dam/downloads/g0/about_us/ logistics_insights/dhl_logistics_trend_radar_2016.pdf.

Palonka, J. (2008). Narzędzia Technologii Informacyjnej wykorzystywane w logistyce w e-gospodarce. In: Systemy Wspomagania Organizacji. Katowice: Wydawnictwo Akademii Ekonomicznej w Katowicach.

Paprocki, W. (2016). Przemysł 4.0 a łańcuch dostaw. Prognozowanie zachowań klientów. Eurologistics, 1, 22-23.

Sah, P. (2016). Saving Environment Using Internet of Things: Challenges and the Possibilities. Advances in Internet of Things, 6 (4), 55-64.

Skowronek, Cz., Sarjusz-Wolski, Z. (1995). Logistyka w przedsiębiorstwie. Warszawa: PWE.

Słownik Języka Polskiego PWN (2017). Retrieved from: https://sjp.pwn.pl.

Supply chain management in the cloud(2018). Accenture 2012. Retrieved from: https://www.accenture.com/t20150523T022449Z__w__/ us-en/_acnmedia/Accenture/Conversion-Assets/DotCom/Documents/Global/PDF/Dualpub_1/Accenture-Supply-ChainManagement-in-the-Cloud.pdf.

Uckelmann, D. (2008). A Definition Approach to Smart Logistics. International Conference on Next Generation Wired/Wireless Networking. NEW2AN 2008: Next Generation Teletraffic and Wired/Wireless Advanced Networking. Berlin: Springer, $273-284$. Retrieved from: https://link.springer.com/chapter/10.1007/978-3-540-85500-2_28.

Valkova, N.V. (2013). E-Logistics: definition and components of its instruments. Modeling of the regional economy. No. 1, 119-128. Retrieved from: http://nbuv.gov.ua/j-pdfModre_2013_1_15.pdf.

Wegener, D. (2015). Industry 4.0 - vision and mission at the same time. Industry 4.0 - Opportunities and challenges of the industrial internet. In: T. Bauernhansl, M. ten Hompel, B. Vogel-Heuser (eds.), Industrie 4.0 in Produktion, Automatisierung und Logistik Anwendung, Technologien, Migration (pp. 343-358). Wiesbaden: Springer.

Weiser M. (1996). Open House. In: Review, March 1996, ITP Review 2.0. Retrieved from: www.itp.tsoa.nyu.edu/ review.

What is Intelligent Supply Chain (2018). Retrieved from: https://www.igi-global.com/dictionary/intelligent-supply-chain-isc/43236.

Wielki, J. (2016). Internet rzeczy i jego wpływ na modele biznesowe współczesnych organizacji gospodarczych. Studia Ekonomiczne. Zeszyty Naukowe Uniwersytetu Ekonomicznego w Katowicach, 281, 208-219.

Windt, K., Hülsmann, M., (2007). Changing Paradigms in Logistics - Understanding the Shift from Conventional Control to Autonomous Cooperation and Control. In: M. Hülsmann, K. Windt (eds.), Understanding Autonomous Cooperation \& Control - The Impact of Autonomy on Management, Information, Communication, and Material Flow (pp. 4-16). Berlin: Springer.

Cite this anticle aS: Dembińska, I. (2018). Smart logistics in the evolution of the logistics. European Journal of Service Management, 3 (27/2), 123-133. DOI: 10.18276/ejsm.2018.27/2-15. 